\title{
E-BRIEF
}

November 2, 2017

FISCAL AND TAX POLICY

\section{Flying Below the Radar: The Harmful Impact of Ontario's Business Property Tax}

by

Adam Found

- Ontario's property tax regime is in need of reform. On efficiency and equity grounds, Ontario's continued application of widely different provincial business property tax rates across and within municipalities and property classes is entirely unjustifiable. Equally unjustifiable is an average provincial business property tax rate that is more than six times its residential counterpart.

- The degree of harm caused by a tax is reflected in how much it reduces its tax base. A 10 percent increase in the average combined provincialmunicipal effective business property tax rate decreases the long-run value of the business property tax base by 8.2 percent. At the average level of business property taxation in Ontario, a $\$ 1.00$ business property tax hike costs the Ontario economy $\$ 5.56$.

- Ontario is collecting $\$ 6$ billion in property tax revenue in fiscal 2017/18. It should commit to a long-term plan to abolish its property tax, leaving the property tax to municipalities. This measure would greatly enhance Ontario's competitiveness and business climate.

In an effort to improve its business and investment climate, Ontario introduced a series of business-tax-related measures between 2004 and 2012. The province eliminated its corporate capital tax, reduced its corporate income tax rate and transformed its retail sales tax into a harmonized value-added sales tax (Ontario 2013). During this period, Ontario also reduced the

The author thanks Benjamin Dachis, Harry Kitchen, members of C.D. Howe Institute Fiscal and Tax Competitiveness Council and anonymous reviewers for comments on an earlier draft. The author retains responsibility for any errors and the views expressed. 
burden of its provincial business property tax, openly acknowledging the tax's harm to the provincial economy (Ontario 2007).

Ontario established its provincial property tax in 1998 when it took over the local education property tax, inheriting from school boards a tax regime with a relatively heavy burden on business and a wide range of tax rates. Ontario's provincial property tax is levied on both residential and business properties, where the latter class is on average burdened with a tax rate more than six times that applied to the former. Despite owning the tax for almost two decades, the province has made limited progress toward reducing its heavy burden on business and the unjustifiably wide variation in tax rates across and within both municipalities and property classes. ${ }^{1}$

With 35 percent of Canadian corporate investment in the form of physical structures and other improvements to land, there is a public policy interest in quantifying the harmful impact of Ontario's business property tax. Such an analysis, which forms the body of this E-Brief, should raise the tax's visibility and make for more informed policy recommendations and decisions (Found 2014b).

The degree of harm caused by a tax is reflected in the amount of tax-base depression it causes. The sensitivity of a tax base to a taxation level is measured by tax elasticity - the percentage reduction in the long-run value of the tax base in response to a one-percent-increase in the effective tax rate. ${ }^{2}$ The more sensitive is the tax base, the greater it is reduced, and the lower the additional revenue generated, by an increase in the effective tax rate.

Another measure of tax harm is the marginal cost of public funds - the dollar amount by which an economy is damaged by raising an additional dollar of revenue through a tax-rate hike (Dahlby et al. 2011). Once the tax elasticity is known, so is the marginal cost of public funds (Found 2014b).

Found (2014b) developed a model to estimate a business property tax's elasticity based on a representative business contemplating an investment in real property where capital (in the form of structures) and land combine to produce floor space under constant returns to scale technology. Calibrating the model to the 2015 business property tax climate in Ontario (see online Appendix), this E-Brief finds:

1 Tax Elasticity. The average tax elasticity for business property taxation in Ontario is estimated to be -0.82 , implying that a 10 percent increase in the average combined provincial-municipal effective tax rate is expected to decrease the long-run value of the business property tax base by 8.2 percent. If the province abolished its business property tax, the tax elasticity would fall to -0.52 , all else equal (including municipal effective business property tax rates).

2 Marginal Cost of Public Funds. At the average level of business property taxation in Ontario, the marginal cost of public funds is estimated to be $\$ 5.56$, implying that a $\$ 1.00$ business property tax hike costs the Ontario economy $\$ 5.56$. If the province abolished its business property tax, the marginal cost would fall to $\$ 2.08$, all else equal (including municipal effective business property tax rates).

1 Adding to the wide variation, provincial business property tax rates are similarly levied in areas without municipal organization.

2 In principle, a tax base can be measured in terms of quantity or value. While both measures are of economic interest, in this study tax elasticity is measured in respect of the value of the tax base, since the property tax is ad-valorem as opposed to excise (i.e., is levied on price or value rather than quantity). 
3 Revenue Generation. The province and its municipalities together extract an estimated 97.5 percent of the long-run maximum revenue potential of the business property tax in Ontario. If the average combined provincial-municipal effective tax rate of 2.30 percent increased to the revenue-maximizing tax rate of 3.02 percent, this would raise only an estimated $\$ 224$ million annually in additional province-wide revenue. $^{3}$

These results suggest long-run business property investment and the tax base are highly sensitive to the property tax, implying Ontario's economy and municipalities would gain considerably from abolition of the provincial business property tax.

\section{Business Investment Taxation: Burden vs. Response}

Taxation can be levied on a stock or a flow. ${ }^{4}$ Corporate income tax is levied on a flow (corporate income net of deductions), while business property tax is levied on a stock (assessed value of business property). A tax levied on any business activity is equivalent to a tax on capital (a stock) and, therefore, on investment (a flow). That is, the burden of any business tax is represented by a premium on the after-tax rate of return on business investment. This wedge driven between the before- and after-tax rates of return on business investment is referred to as the marginal effective tax rate (METR) (Found et al. 2016).

While the METR is a widely accepted standardized measure of the burden of a business tax, it gives no indication of the extent to which businesses respond to that burden. In other words, the METR measures the increase in the marginal cost of business investment, but not the resulting reduction in business investment. However, tax elasticity is useful for measuring that reduction. Of further interest, once the tax elasticity is known or estimated, other relevant functions of the effective tax rate can be constructed, such as the marginal cost of public funds and the share of maximum revenue generated. These provide additional insights into the impact of business taxation.

\section{Provincial and Municipal Property Taxation in Ontario}

Ontario is similar to most other provinces in that both the province and its municipalities independently levy a property tax, but the provincial tax is more problematic for three reasons:

1 Tax Rate Variance. All else equal, municipal property tax rates vary with local public service levels, supporting efficient allocation of property investment and equitable tax-service treatment of property. By contrast, arbitrary variation in property tax rates, as occurs with the provincial property tax, distorts property investment in favour of some localities and property classes at the expense of others. Such variation is inefficient and inequitable.

3 The additional revenue estimate is based on increasing all business property tax rates by the same percentage. A larger (smaller) estimate would arise if lower-than-average rates were increased proportionately more (less) than higherthan-average rates.

4 A stock is an economic quantity that is defined with respect to a designated point in time. The value of a vehicle, for example, is a stock as it is measured in dollars at a particular date. By contrast, a flow is an economic quantity that is defined with respect to a designated period of time. For example, personal income is a flow as it is measured in dollars per year. 
2 Function of the Property Tax. The property tax is intended for, and particularly well suited to, the financing of municipal services. However, the province takes about 27 percent of all property tax revenues raised in Ontario. As a result, there is a strong case for the province to vacate the property tax to enhance the financial position and autonomy of municipalities, promote fiscal federalism and set clearer lines of fiscal accountability (Bird, et al., 2012).

3 Availability of Other Taxes. Unlike municipalities, for whom the property tax is essentially the only tool available to raise own-source revenue for public services, the province enjoys great latitude over several more appropriate and less damaging general revenue taxes.

While this E-Brief primarily concerns the provincial business property tax, it also examines the provincial residential property tax and the municipal property tax to provide context. In particular, aggregation of provincial and municipal business property taxes is required for accurate estimation of the harmfulness of taxation.

\section{Tax Levies and Average Tax Rates}

In 2015, the province and its municipalities collected $\$ 26$ billion in property taxes, $\$ 17.1$ billion from residences and the remaining $\$ 8.9$ billion from businesses (Table 1). ${ }^{5}$ Of the $\$ 8.9$ billion levied on the business property classes (i.e., commercial, industrial, pipeline, etc.), the province collected $\$ 3.8$ billion (43 percent).

Table 2 translates the assessments and tax levies in Table 1 into province-wide average statutory and effective tax rates. ${ }^{6}$ The 2015 average combined provincial-municipal effective residential and business property tax rates were 0.87 percent and 2.30 percent, respectively (Table 2 ).

Tables 1 and 2 suppress various complexities of Ontario's property tax system. For example, there are special business subclasses for vacant and excess land that receive considerable discounts (typically 30 percent to 35 percent) on statutory tax rates, unless municipalities opt out. ${ }^{7}$ There are potentially several more subclasses subject to differential tax rates depending on whether municipalities adopt local property subclass options available under the Municipal Act. ${ }^{\mathbf{8}}$

5 With complete 2016 Municipal Financial Information Return data unavailable as of this writing, currency of the analysis herein is restricted to 2015 .

6 Given Ontario's four-year assessment cycle, where reassessment is conducted in years divisible by four and value increases are phased in evenly over the cycle, 2015 (unphased) assessed values reflect a valuation date of Jan. 1, 2012 and are, therefore, three years behind 2015 market values. Based on MPAC (2016), the average annual provincial residential and business property appreciation rates over the 2012 to 2015 period were 4.5 percent and 4.15 percent, respectively.

7 Vacant and excess land discounts result in the understatement of effective tax rates faced by property investment as the discounts no longer apply upon development of land.

8 See Bird, Slack and Tassonyi (2012) for a complete and informative review of Ontario's property tax system. In areas of the province without municipal incorporation, Ontario levies the Provincial Land Tax to help support local services provided therein by the province. Tables 1 and 2 exclude the Provincial Land Tax and associated assessment, but include payments-in-lieu of taxation made by senior levels of government. Furthermore, provincial residential property tax revenues (Table 1) and rates (Table 2) are gross of the Ontario Senior Homeowners' Property Tax Grant and the property tax component of the Ontario Energy and Property Tax Credit, which benefit residential taxpayers only. 


\begin{tabular}{|c|c|c|c|c|c|c|c|c|}
\hline \multirow{2}{*}{$\begin{array}{l}\text { Property } \\
\text { Type }\end{array}$} & \multicolumn{2}{|c|}{$\begin{array}{l}\text { Assessment } \\
\text { (Tax Base) }\end{array}$} & \multicolumn{2}{|c|}{ Provincial Levy } & \multicolumn{2}{|c|}{ Municipal Levy } & \multicolumn{2}{|c|}{ Total Levy } \\
\hline & $\begin{array}{c}\text { Value } \\
\text { (\$ billion) }\end{array}$ & $\begin{array}{c}\text { Share } \\
\text { (percent) }\end{array}$ & $\begin{array}{c}\text { Value } \\
\text { (\$ billion) }\end{array}$ & $\begin{array}{c}\text { Share } \\
\text { (percent) }\end{array}$ & $\begin{array}{c}\text { Value } \\
\text { (\$ billion) }\end{array}$ & $\begin{array}{c}\text { Share } \\
\text { (percent) }\end{array}$ & $\begin{array}{c}\text { Value } \\
\text { (\$ billion) }\end{array}$ & $\begin{array}{c}\text { Share } \\
\text { (percent) }\end{array}$ \\
\hline Residential & $1,732.8$ & 83.5 & 3.2 & 45.3 & 13.9 & 73.5 & 17.1 & 65.9 \\
\hline Business & 341.6 & 16.5 & 3.8 & 54.7 & 5.0 & 26.5 & 8.9 & 34.1 \\
\hline Total & $2,074.4$ & 100.0 & 7.0 & 100.0 & 19.0 & 100.0 & 26.0 & 100.0 \\
\hline
\end{tabular}

\begin{tabular}{|l|c|c|c|c|c|c|}
\hline \multirow{2}{*}{ Table 2: Average Ontario Provincial and Municipal Property Tax Rates (2015) } \\
\hline \multirow{2}{*}{$\begin{array}{c}\text { Property } \\
\text { Type }\end{array}$} & \multicolumn{2}{|c|}{ Provincial } & \multicolumn{2}{c|}{ Municipal } & \multicolumn{2}{c|}{ Total } \\
\cline { 2 - 7 } & Statutory & Effective & Statutory & Effective & Statutory & Effective \\
\hline Residential & 0.18 & 0.16 & 0.80 & 0.71 & 0.99 & 0.87 \\
\hline Business & 1.13 & 1.00 & 1.47 & 1.30 & 2.60 & 2.30 \\
\hline Source: Schedule 26 of the Municipal Financial Information Return (FIR) for 2015; MPAC (2016); author's calculations.
\end{tabular}

\section{Ontario's Provincial Property Tax Regime: Complex, Opaque, Inequitable and Unaccountable}

Since taking over the education property tax from Ontario school boards in 1998, the province has funded each school board via two main sources: education property tax revenue generated within the school board's jurisdiction and a provincial top-up grant in accordance with a prescribed formula (Ontario 2017a). Since education tax revenue falls far short of every school board's actual expenditure, the presence of the top-up grant means each board's spending is independent of the education tax revenue raised in its jurisdiction. Even though this tax revenue passes directly through municipalities (which are legislated to collect the tax and remit it to school boards), it is reported as revenue in provincial budgets, as it should be, alongside other provincial revenues.

Ontario's property tax regime is unnecessarily complex and inequitable. It levies business property tax rates that arbitrarily differ by municipality, by property class within a municipality, by property within a property class and even by component of a single property's assessment. ${ }^{9}$ To the author's knowledge, the province is unique in 
Canada in this regard. Contributing significantly to this inequity is the unwarranted disparity between provincial residential and business property tax rates. As implied by Table 2, the average provincial business property tax rate is about 6.25 times its residential counterpart, whether calculated on a statutory or effective basis (once corrections for rounding in Table 2 are made).

A provincial statutory tax ratio of 6.25 is far in excess of not only its municipal counterpart of 1.84 (as implied by Table 2) but also the upper bound of the commercial/industrial "allowable range" of 0.6 to 1.1 established by the Municipal Act for municipal commercial/industrial statutory tax ratios. In respect of a property class, this allowable range prescribes the tax ratio interval over which municipalities may freely change the tax ratio (Ontario, 2002). A municipal tax ratio already below (above) this range cannot be decreased (increased), unless the change is strictly to offset a reassessment-related redistribution of the tax levy across property classes. While Ontario at times refers to the allowable range as the "range of fairness," it does not apply this standard to its own property tax (Ontario 2002). Accordingly, a provincial tax ratio of 6.25 would appear to be grossly unfair and hypocritical.

Ontario's property tax regime also remains unjustifiably unaccountable and opaque. The province still refers to its property tax as the "Education Tax," which is misleading since, as noted above, property tax revenue in no school board determines education expenditure. Moreover, since taking over the property tax from school boards, Ontario has never disclosed the manner in which tax rates are determined for each municipality and property class. Each year, the tax rates are simply listed in a regulation without explanation or background information. Under the Education Act, the minister of finance can arbitrarily set the tax rates across all property classes and all 444 municipalities in Ontario.

\section{Ontario's Business Property Tax Reduction Program: A Broken Promise?}

Upon assuming the local education property tax in 1998, the province inherited a set of business education tax rates (now provincial business property tax rates) with wide variation across and within municipalities. This variation was a natural and direct result of school boards' pre-1998 prerogative to set education service levels and tax rates in accordance with local circumstances. While the province immediately harmonized residential property tax rates in 1998, it continues to levy a business property tax with wide-ranging rates and a heavy burden.

During the 1998-2002 period, the government reduced the provincial business property tax burden where it was highest (Ontario 2003). For businesses in those municipalities not receiving such reductions, the province adjusted tax rates annually on a revenue-neutral basis, offsetting the effects of reassessment. These adjustments took place within each business property class at the municipality level. Between 2003 and 2007, the government discontinued the levy reductions and extended the revenue-neutral approach to all municipalities, leaving intact the remaining wide variation in, and heavy burden of, provincial business property tax rates.

In its 2007 budget, the province acknowledged the need to further reduce the burdens and inequities engendered by its business property tax regime:

Business representatives, including the Ontario Chamber of Commerce and Canadian Federation of Independent Business, have criticized high BET (business education tax) rates as being unfair and as being

9 As a result of the the 2007-2014 provincial business property tax reduction program, there are business properties split between the default tax rate applicable in their municipality and the province-wide new construction tax rate. See Box 1 for further details on the program. 
a barrier to economic competitiveness. The variation in rates distorts efficient business location decisions placing many regions of the province at a disadvantage and harming the provincial economy overall.

Cutting high BET rates will result in economic benefits to Ontario in terms of increased jobs, investment, productivity and output. The economic benefits of this initiative will be widespread. In fact, businesses in northern Ontario will be the largest beneficiaries of the BET cuts, with an average percentage decrease of 32 per cent (Ontario 2007).

In the same budget, the government initiated a new provincial business property tax reduction program designed to address these concerns by reducing the burden by $\$ 540$ million annually through progressively truncating the range of business property tax rates between 2008 and 2014. In essence, the program implemented dollar-value tax cuts for municipalities with the highest-taxed business property classes, whereby a ceiling tax rate would be gradually reduced toward a target tax rate. (See Box 1 for details.)

In light of difficult fiscal circumstances in 2012, the province suspended the larger tax cuts planned for 2013 and 2014, amounting to more than $\$ 300$ million per year of relief deferred to 2017 and 2018 to assist the government in returning to a balanced budget by fiscal 2017/18 (Ontario 2012). Despite the province having achieved budget balance, the 2017 Ontario budget makes no reference to the 2007 commitment nor to the 2012 revised commitment, suggesting the commitments will not be met (Ontario 2017b).

\section{Impact of Business Property Taxation in Ontario}

Business property taxes discourage investment in the same way as other economically harmful taxes such as corporate income or corporate capital taxes (Dahlby 2012; Found et al. 2016). The business property tax depresses its tax base through two distinct yet easily conflated effects: capitalization and disinvestment. The first is the effect the tax has on the value of existing property (i.e., land and existing improvements to land), while the second is the effect on the value of new (i.e., prospective) improvements to land (e.g., development, redevelopment, demolition, renovation, site preparation, landscaping, etc.).

For any given increase in the effective tax rate, both effects reduce the revenue increase that would otherwise materialize in the long run. The combined effect of capitalization and disinvestment is measured by tax elasticity - the percentage reduction in long-run tax base value from a one percent increase in the effective tax rate. The effect can also be measured as the proportion of the tax base retained at a given effective tax rate. Both functions can be graphed against the effective tax rate.

As with any tax on a producible and mobile base (e.g., structure investment), the business property tax is subject to revenue generation limitations. Not only is taxation subject to long-run diminishing returns on effective tax rate increases, but there exists an effective tax rate sufficiently high whereby an increase to it will result in a reduction in long-run tax revenue. ${ }^{10}$ The interaction of capitalization, disinvestment and revenue generation is captured in the "revenue hill," a function relating long-run revenue potential to the effective tax rate.

10 It can be shown that the capitalization effect is insufficient to bring about this result; it is the disinvestment effect that is the ultimate limitation on long-run revenue (Oates, et al., 2009). 


\section{Box 1: Structure of the 2007-2014 Provincial Business Property Tax Reduction Program}

As outlined in the 2007 Ontario budget, the tax reduction program comprised three components:

1. Target Tax Rate. A target tax rate of 1.60 percent was set so as to deliver $\$ 540$ million annually in provincial business property tax reductions. a The target rate would be adjusted annually as needed to account for the effects of reassessment. For 2017, the target rate is 1.14 percent.

2. Declining Ceiling Tax Rates. The $\$ 540$ million in annual relief was to be phased in between 2008 and 2014 in a back-ended fashion, with the majority of the reduction implemented in 2013 and 2014. Ceiling rates for each business property class were set to deliver $\$ 15$ million per year in relief in 2008. ${ }^{\mathbf{b}}$ The remainder of the phase-in was to be facilitated by decreasing the ceiling tax rates until they eventually dropped to the target rate in 2014 . The ceiling tax rates would be adjusted annually as needed to account for the effects of reassessment. For 2017, the ceiling rate for all business property classes is 1.39 percent. This is higher than the 1.14 percent target rate for 2017 since the 2013 and 2014 components of the program were deferred as per the 2012 Ontario budget.

3. New Construction. As an added measure to alleviate the tax burden on business investment, new construction occurring after March 22, 2007, the day of the budget speech, would be taxed at the lower of the target rate or the rate otherwise applicable. ${ }^{\mathrm{c}}$

a Subject to rate adjustments as a result of reassessment, the target rate would not apply to municipalities with provincial business property tax rates already lower than the target.

b The initial ceiling rates were 2.50 percent for commercial and 3.00 percent for industrial and pipeline.

c Section 15 of the Education Act amends the Assessment Act to define "new construction" as improvements to land initiated by application for a building permit after March 22, 2007 (the day of the 2007 Ontario budget) such that the improvements increase the property's assessed value by at least 50 percent.

Drawing on the model developed in Found (2014b), functions of the effective business property tax rate are definable for (i) tax elasticity, (ii) share of tax base retained and (iii) share of maximum revenue raised (i.e., revenue hill). See the online Appendix for a summary of model inputs and outputs. ${ }^{11}$ Having been calibrated to Ontario for 2015, these functions are illustrated in Figure 1, where the provincial average is indicated. ${ }^{\mathbf{1 2}}$

11 The revenue hill is defined as a proportion so as to enable it to be graphed with the other functions and without the need to measure it in dollars.

12 As is mathematically required, the tax elasticity and revenue hill functions intersect when the effective tax rate is zero and where it is equal to the revenue-maximizing tax rate. 


\section{Figure 1: Long-Run Impact of the Business Property Tax in Ontario}

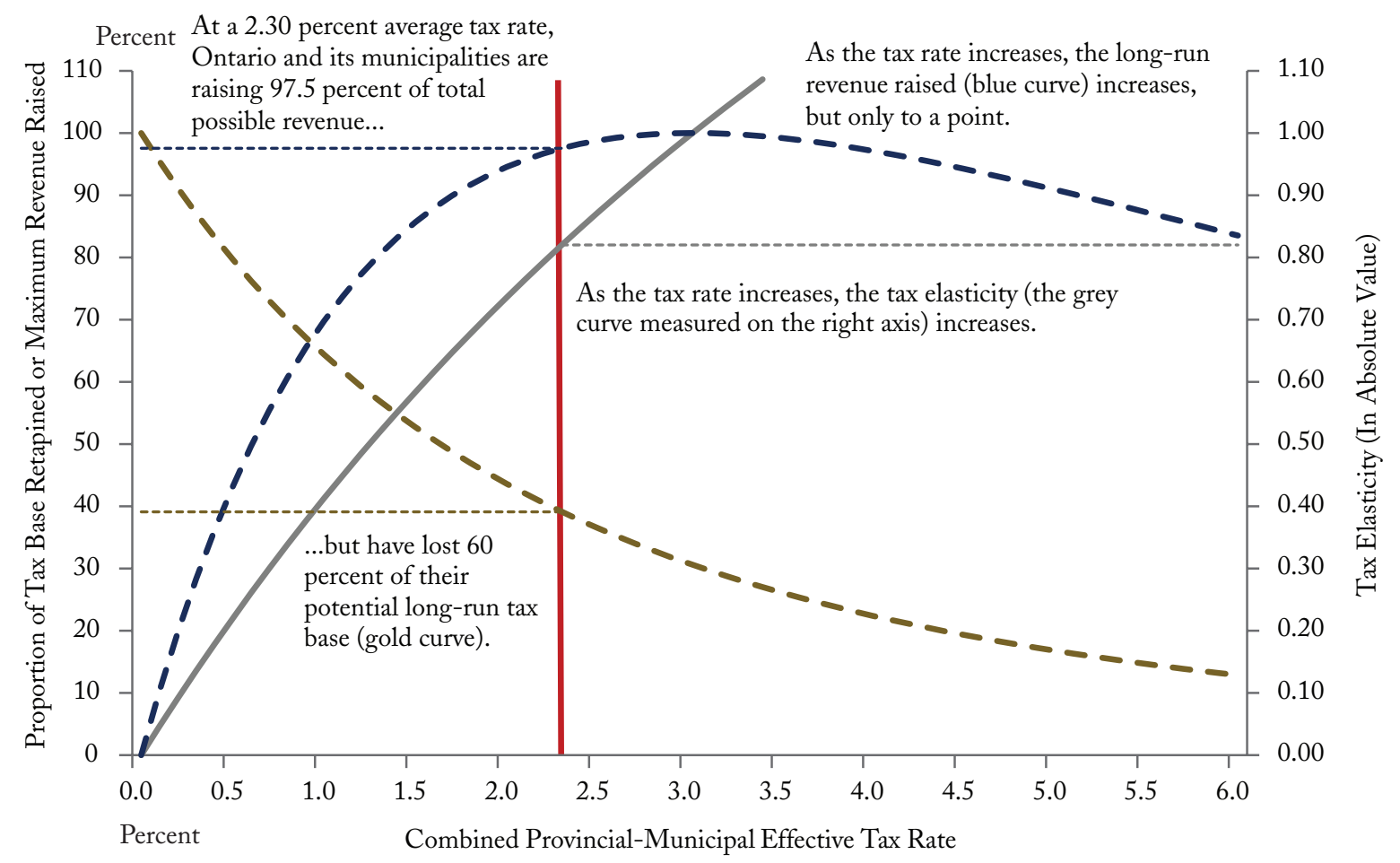

- - Maximum Revenue Raised - - Tax Base Retained _ Absolute Value of Tax Elasticity (Right Axis)

Source: Author's calculations.

Figure 1 provides some interesting insights. The tax elasticity function suggests the average tax elasticity for the business property tax in Ontario is -0.82 , given the average effective tax rate is 2.30 percent as determined in Table 2. This implies that a 10 percent increase in the average effective tax rate is estimated to reduce the longrun value of the tax base by 8.2 percent, suggesting businesses are, at current taxation levels, highly sensitive to the tax in the long run. This result further implies the marginal cost of public funds associated with the business property tax is $\$ 5.56$, meaning the Ontario economy is damaged by this amount for every additional dollar of revenue raised by increasing the average effective tax rate.

The revenue hill function suggests the province and its municipalities have almost exhausted (97.5 percent) the maximum long-run revenue potential of the business property tax. Based on an $\$ 8.9$ billion levy in 2015 , this implies only about $\$ 224$ million per year in additional province-wide revenue could be extracted from the business property tax by uniformly increasing all tax rates such that the provincial-municipal average effective tax rate increases to 3.02 percent, the revenue-maximizing effective tax rate according to the revenue hill. 


\section{Recommendations}

The foregoing review and analysis suggest several reforms for Ontario's property tax regime. On efficiency and equity grounds, Ontario's continued application of widely different provincial business property tax rates across and within municipalities and property classes is entirely unjustifiable. Equally unjustifiable is an average provincial business property tax rate that is more than six times its residential counterpart. Regardless of how politically invisible the provincial property tax might be perceived, the economic harm associated with its burden and inequities exists nonetheless.

Ontario estimates it will collect $\$ 6$ billion in property tax revenue in fiscal $2017 / 18$, net of the Ontario Senior Homeowners' Property Tax Grant and the property tax component of the Ontario Energy and Property Tax Credit (Ontario 2017b). In accordance with the principles of fiscal federalism and economic competitiveness, Ontario should commit to a long-term plan to abolish its property tax (e.g., reduce the net burden by about $\$ 300$ million annually over 20 years), leaving the property tax to municipalities. ${ }^{13}$ This measure would greatly enhance Ontario's competitiveness and business climate, and it can be strategically absorbed into the provincial budget over time.

In addition to imposing the "allowable range" on business property tax ratios, the Municipal Act requires residential property tax increases in municipalities with relatively high business property tax ratios to be at least twice as high as those faced by businesses. In addition to gradually reducing municipalities' over-reliance on business property taxation, these restrictions ought to provide business property sufficient protection from municipal tax increases designed to occupy property tax room vacated by the provincial business property tax, just as they did during the 2008-2012 provincial business property tax reductions.

If, instead, Ontario decides to retain its property tax, it should immediately establish a program aimed at tax-rate harmonization across all municipalities and property classes. As with the 2007 program, this could be based on a declining ceiling tax rate that delivers targeted dollar-value tax cuts absorbed into the provincial budget. Ultimately, the program should aim at harmonizing business property tax rates downward to the uniform residential rate. This would considerably enhance Ontario's competitiveness and business climate, but less so than abolition of the provincial property tax.

Much improvement to provincial accountability and transparency is also needed if Ontario keeps its property tax. It should discontinue using the misleading name "Education Tax" for what is clearly a provincial general revenue tax that has no bearing on school board expenditures. That is, the fiscal function of provincial property tax revenue is identical to any other provincial general tax revenue. The province requires municipalities to publicly link budget and property tax decisions on an annual basis, making the determination of property tax rates transparent and ensuring municipalities are held accountable for those decisions. However, the province holds itself to no such standard for its property tax. It is not enough to simply state provincial property tax rates quietly in a regulation each year; Ontario should make annual property-tax-rate determinations public and transparent, including the government policies underlying annual tax rate changes.

13 Ideally, this would occur in two phases. First, business property tax rates would be gradually reduced to the uniform residential rate, resulting in a province-wide ceiling rate across all property classes. Second, the province-wide ceiling rate would be gradually reduced until it reaches zero, capturing all lower rates, if any exist at that time, along the way. Abolishment of the provincial property tax aligns with one of the central recommendations in Bird, Slack and Tassonyi (2012). 


\section{Conclusions}

Ontario's business property investment and tax base are highly sensitive to the business property tax. Under 2015 conditions, a 10 percent increase in the average combined provincial-municipal effective tax rate is estimated to reduce the business tax base and investment by 8.2 percent compared to what they would otherwise be. This finding suggests the business property tax is harmful and inefficient compared to value-added and land-value taxes.

Several reforms are needed to improve Ontario's provincial property tax as it relates to the principles of efficiency, equity, transparency, simplicity, accountability, competitiveness and fiscal federalism. The simplest and most effective measure would be abolishing the provincial property tax, leaving the property tax at the local level to finance municipal and other local public services transparently and accountably. 


\section{References}

Bird, Richard, Enid Slack, and Almos Tassonyi. 2012. A Tale of Two Taxes: Property Tax Reform in Ontario. Toronto: Lincoln Institute of Land Policy.

Dahlby, Bev, and Ergete Ferede. 2011. What Does it Cost Society to Raise a Dollar of Tax Revenue. Toronto: C.D. Howe Institute.

Dahlby, Bev. 2012. Reforming the Tax Mix in Canada. University of Calgary. Calgary: The School of Public Policy.

Found, Adam, and Peter Tomlinson. 2016. Business Tax Burdens in Canada's Major Cities: The 2016 Report Card. Toronto: C.D. Howe Institute.

Found, Adam. 2014a. Business Property Taxes and the Marginal Effective Tax Rate on Capital. Department of Economics, University of Toronto. Toronto: Ph.D. Dissertation Chapter.

. 2014b. The Effect of Commercial Property Taxes on Structure Investment and the Tax Base. Department of Economics, University of Toronto. Toronto: Ph.D. Dissertation Chapter.

Municipal Property Assessment Corporation. 2016. [Online] 2016. [Cited: September 9, 2017.] https:// www.mpac.ca/Media/PressReleases.

Oates, Wallace, and Robert Schwab. 2009. "The Simple Analytics of Land Value Taxation." Richard Dye and Richard England (editors). Assessing the Theory and Practice of Land Value Taxation. Cambridge : Lincoln Institute of Land Policy, 2009, pp. 51-72.

Ontario. 2002. Property Assessment and Classification Review. Toronto: Government of Ontario.

- 2003.2003 Ontario Budget. Toronto: Government of Ontario.

- 2007.2007 Ontario Budget. Toronto: Government of Ontario.

- 2008. 2008 Ontario Budget. Toronto: Governmet of Ontario.

- 2012.2012 Ontario Budget. Toronto: Government of Ontario.

- 2013.2013 Ontario Budget. Toronto: Government of Ontario.

- 2016.2016 Ontario Budget. Toronto: Government of Ontario.

- 2017a. School Funding - A Guide for Parents. Toronto: Government of Ontario.

- 2017b. 2017 Ontario Budget. Toronto: Government of Ontario.

This E-Brief is a publication of the C.D. Howe Institute.

Adam Found is Metropolitan Policy Fellow at the C.D. Howe Institute and Course Instructor, Trent University.

This E-Brief is available at www.cdhowe.org.

Permission is granted to reprint this text if the content is not altered and proper attribution is provided. 